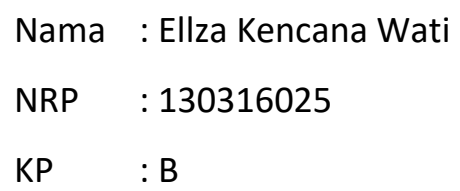

\title{
REVIEW JURNAL INTERNASIONAL
}

Pada saat ini, jumlah penduduk Indonesia yang menggunakan internet mencapai lebih dari $50 \%$ dari keseluruhan populasi, dengan tingkat pengeluaran rata - rata mencapai Rp 6.5 juta dalam setahun yang digunakan untuk berbelanja online. Pada saat ini pula, dunia telah memasuki era industry 4.0 yang didasarkan pada adanya teknologi baru yang terus berkembang. Industri ini berkembang pesat di Indonesia, hal ini ditandai dengan banyaknya kemunculan e -commerce serta pembayaran dengan menggunakan media elektronik. Adanya fenomena seperti ini menandakan bahwa teknologi mampu memainkan peranan yang strategis dalam memberikan pelayanan bagi masyarakat. Hal ini tentunya sejalan dengan keinginan masyarakat yang menuntut adanya pelayanan yang lebih cepat tanpa harus menunggu lama. Saat ini pula pelayanan keuangan dalam perbankan telah berkembang seperti adanya mobile banking, internet banking, virtual credit card, dan masih banyak lainnya. Singapura, Jepang, dan Inggris merupakan tiga negara yang telah mampu membuktikan adanya dampak signifikan dari teknologi keuangan terhadap pertumbuhan ekonomi dan stabilitas keuangan. Dengan adanya teknologi keuangan, pedangan kecil dapat menerima pembayaran debit dan kartu kredit berbiaya rendah sehingga meningkatkan daya beli masyarakat.

Kehadiran era ekonomi digital tentunya membawa peluang yang besar bagi masyarakat sekaligus dapat menjadi ancaman yang serius bagi industry perbankan yang sudah banyak beralih ke perbankan digital untuk mempertahankan pelanggan yang telah ada maupun menarik pelanggan yang baru yang berasal dari generasi milenial.

Pertumbuhan ekonomi di Indonesia dimasa depan membutuhkan sektor keuangan yang stabil bekisar 6\% 6\% per tahun. Ini berarti bahwa bank, asuransi, pasar modal dan perusahaan pemula harus dipacu sehingga pertumbuhan kredit tahunan tidak lagi di kisaran 10-12\%. Hal ini dimaksudkan agar pertumbuhan kapasitas sektor keuangan Indonesia dapat meningkat hingga lima kali lipat. Namun hal yang harus diketahui industry pada jasa keuangan adalah industry yang paling rentan terhadap kecurangan, apalagi masyarakat Indonesia belum banyak yang terdidik mengenai ancaman digital. 
Sistem keuangan membutuhkan stabilitas keuangan untuk menghindari krisis moneter. Stabilitas keuangan adalah suatu kondisi di mana mekanisme ekonomi dalam penetapan harga, alokasi dana, dan manajemen risiko dapat berfungsi dengan baik dan mampu mendukung pertumbuhan ekonomi. Sistem keuangan yang stabil adalah sistem yang mampu mengalokasikan sumber daya keuangan serta dapat melakukan fungsi perantara, melakukan pembayaran dan menyebarkan resiko dengan tepat. Sistem keuangan juga diharapkan mampu menjalankan fungsinya sebagai pengumpul dan penyalur dana publik secara maksimal yang pada gilirannya dapat mempengaruhi sirkulasi pasokan uang di masyarakat, membuat Inflasi terkendali dan mendorong sektor primer, sekunder, dan tersier. Di Indonesia, jumlah uang yang beredar diatur oleh Bank Indonesia untuk mencegah adanya inflasi.

Perkembangan dan kemajuan teknologi menyebabkan jumlah rata - rata uang tunai yang dipegang oleh individu mengalami penurunan. James Tobin berpendapat bahwa ketidakkonsistenan antara pengeluaran dan penerimaan pendapatan memaksa individu untuk menyediakan instrumen pembayaran untuk membiayai transaksi mereka, dan tidak harus dalam bentuk tunai.

Industri 4.0 membutuhkan teknologi untuk semua lini. Selain itu perilaku masyarakat juga berubah dari segi sosial maupun ekonomi. Pada era ini, semua masyarakat cenderung lebih menggunakan transaksi berbasis digital dalam kehidupan sehari - hari. Saat ini, internet memiliki peran besar dalam mendorong pertumbuhan ekonomi, memperluas kesempatan kerja, dan meningkatkan layanan publik. Disini seharusnya masyarakat melihat hal ini sebagai peluang bisnis yang baru karena pemerataan akses ke adopsi digital adalah langkah untuk mengurangi ketidaksetaraan perkembangan suatu negara.

Pada saat ini masyarakat telah menunjukkan perkembangan yang positif mengenai adanya teknologi dalam setiap kegiatan transaksi. Hal ini dibuktikan adanya penggunaan saldo e-money yang meningkat dari Rp5 juta menjadi Rp10 juta. Transaksi berbasis kartu akan meningkat seiring dengan perkembangan pembayaran elektronik yang terhubung dengan jaringan ATM dan EDC.

Negara seperti Amerika dan China membuktikan bahwa dengan adanya inovasi yang dapat dipahami oleh masyarakat membuat sumber daya manusia yang kurang berkompeten menjadi lebih berkompeten. Pada era digital tahun 2030 dapat dikatakan berbeda dari periode sebelumnya karena telah memiliki teknologi canggih serta mengubah ekosistem masyarakat dan mengubah 
cara hiduo masyarakat. Saat ini saja, masyarakat sudah dibekali dengan adanya smartphone yang sangat memudahkan masyarakat dalam melakukan pengiriman dan penerimaan pesan.

Pesatnya pertumbuhan dan kemajuan teknologi di Indonesia juga diharapkan mampu mendorong industry kreatif, perusahaan startup, serta UMKM dan berbagai institusi yang berbasis teknologi di Indonesia.Hal ini juga diperlukan keikutsertaan dari pemerintah dalam mendukung penggunaan teknologi dalam proses bisnis di Indonesia sehingga hal ini dapat memberikan akses yang adil dan mampu memajukan industri keuangan yang dapat mempertahankan modal dan meningkatkan produksi UMKM serta pertumbuhan ekonomi di Indonesia. Hal ini dibuktikan dengan banyaknya UMKM yang berhasil meningkatkan angka penjualannya dengan menggunakan transaksi yang berbasis digital. Namun, masih banyak sekali UMKM yang belum memahami proses transaksi dengan cara yang seperti ini, sehingga UMKM tersebut tidak berkembang. Tentunya diperlukan pendampingan dan penyuluhan yang tepat terhadap UMKM tersebut agar mampu bersaing dalam dunia bisnis.

Pada saat ini telah muncul layanan industry teknologi keuangan berbasis investasi yang dikenal sebagai Equity Crowdfunding (EC). Dimana EC ini menggunakan modal dari sejumlah individu dengan latar belakang investor untuk membiayai bisnis baru dengan memanfaatkan akses jaringan media sosial dan platform crowdfunding. Dengan adanya EC, diharapkan UMKM serta bisnis startup mendapat kemudahan dalam mencari dana untuk menjalankan proses bisnisnya. 